\title{
МЕТОДИКА НАВЧАННЯ МАЙБУТНІХ ПЕРЕКЛАДАЧІВ УСНОГО ПОСЛІДОВНОГО НАУКОВО-ТЕХНІЧНОГО ПЕРЕКЛАДУ
}

\author{
Володько А. М. \\ annamvolodko@gmail.com \\ Національний технічний університет Украӥни \\ "Київський політехнічний інститут імені Ігоря Сікорського" \\ Дата надходження 23.04.2018. Рекомендовано до друку 28.05.2018.
}

\begin{abstract}
Анотація. Статтю присвячено проблемі навчання майбутніх перекладачів усного послідовного науково-технічного перекладу. Представлено обгрунтування, результати практичного розроблення й експериментальної перевірки методики навчання усного послідовного науково-технічного перекладу 3 використанням ділової гри та з урахуванням готовності студентів до навчання і виконання завдань, які імітують реальну професійну перекладацьку ситуацію проблемного й проблемно-пошукового характеру. Конкретизовано цілі й складники змісту навчання усного послідовного перекладу студентів четвертого курсу. Уточнено й визначено поняття “усний послідовний переклад” і “навчання усного послідовного перекладу” в підготовці студентів мовних спеціальностей закладу вищої освіти. Досліджено компоненти перекладацької компетентності, які сформовано на початку навчання та формуються під час навчання усного послідовного перекладу. Представлено результати експериментального навчання усного послідовного науково-технічного перекладу.

Ключові слова: майбутні перекладачі, усний послідовний переклад, науково-технічний переклад, перекладацька компетентність, готовність до навчання.
\end{abstract}

Володько А. Н. Национальный технический университет Украины “Киевский политехнический институт имени Игоря Сикорского"

Методика обучения будущих переводчиков устному последовательному научно-техническому переводу

Аннотация. Статья посвящена проблеме обучения будущих переводчиков устному последовательному научно-техническому переводу. В статье представлено обоснование, практическая разработка и результаты экспериментальной проверки методики обучения устному последовательному научно-техническому переводу с использованием деловой игры и с учетом готовности студентов к обучению и выполнению задач, имитирующих реальную профессиональную переводческую ситуацию проблемного и проблемнопоискового характера. Конкретизированы цели и составляющие содержания обучения устному последовательному переводу студентов четвертого курса. Уточнены и определены понятия “устный последовательный перевод” и “обучение устному последовательному переводу” в подготовке студентов языковых специальностей вуза. Исследованы компоненты переводческой компетентности, которые сформированы до начала обучения и формируются во время обучения устному последовательному переводу. Представлены результаты экспериментального обучения устному последовательному научнотехническому переводу.

Ключевые слова: будущие переводчики, устный последовательный перевод, научно-технический перевод, переводческая компетентность, готовность к обучению.

Volodko A. National Technical University of Ukraine "Igor Sikorsky Kyiv Polytechnic Institute" Methodology of teaching prospective interpreters consecutive scientific and technical interpreting Abstract. Introduction. Different issues of consecutive interpreting has been studied by scientists, but the lack of a developed and scientifically based method of teaching consecutive scientific and technical interpreting, taking into account possible difficulties in the process of its teaching and performance, has determined the relevance of our study. Purpose. The research is based on theoretical substantiation, practical development and experimental verification of the teaching methodology of the consecutive scientific and technical interpreting, taking into account the level of students' readiness to carry out translation activities. Methods. The thesis provides theoretical substantiation and practical elaboration of the methodology of teaching future interpreters consecutive scientific 
and technical interpreting. Results. Within the framework of the study, the stages of consecutive interpretation have been clarified; a subsystem of exercises and a model for teaching consecutive scientific and technical interpreting have been developed. The effectiveness of the implemented training methodology has been verified and proved experimentally. The methodological recommendations for the outure interpreters' training to perform consecutive scientific and technical interpreting have been suggested. Conclusion. To sum up, it has been found that the transition from the rigid to the flexible degree of controllability of the educational process enhances the reflexive abilities of students. The results of experimental studies, which confirmed the effectiveness of the developed methodology, give grounds to recommend it for teaching consecutive interpreting to the students majoring in Translation.

Key words: prospective interpreters, consecutive interpreting, scientific and technical interpreting, translation competence, interpretingreadiness..

Постановка проблеми. Курс України на європейську інтеграцію сприяє розвитку нових галузей науки й техніки в країні, що в майбутньому передбачає створення нових підприємств й організацій і залучення іноземних інвестиційних потоків. Інноваційні галузі, потребу в яких мають не тільки державні й приватні установи, але й суспільство в цілому, створюють нові робочі місця й висувають нові вимоги перед співробітниками, а саме: високий рівень професійної кваліфікації технічного персоналу, достатній для ділових переговорів і міжнародної співпраці рівень володіння іноземною мовою (IM) і наявність перекладачів зі знанням понятійної бази спеціальності для роботи із закордонними партнерами. Постійна потреба в інноваціях сприяє швидкій переорієнтації закладів вищої освіти з навчання фахівців за вимогами нового соціального замовлення на підготовку висококваліфікованих працівників у різних галузях науки й техніки, зокрема перекладачів науково-технічних текстів.

Аналіз останніх досліджень і публікацій. Проблемі перекладу приділяла увагу велика кількість фахівців, які досліджували різні питання: теоретичні й психологічні аспекти процесу перекладу (І.О. Зимня, В.Н. Крупнов, А.Ф. Ширясв), комунікативний підхід до навчання перекладу (О. Каде, Л.К. Латишев, З.Д. Львовская, Р.К. Міньяр-Белоручєв, Г.В. Чернов, А.Д. Швейцер), проблеми теорії усного послідовного перекладу (УПП) і синхронного перекладу (Р.К. Міньяр-Белоручєв, Г.А. Самойленко, Г.В. Чернов, А.Ф. Ширяєв), навички й уміння як складники перекладацької компетентності (Н.М. Гавриленко, Я.Б. Смельянова, І.К. Забродіна, W. Kutz, РACTE group), умови функціонування розумових механізмів перекладача під час УПП і психолінгвістичні моделі перекладу (Р.К. Міньяр-Белоручєв, Л.М. Черноватий, E. Lauterbach, B. Moser-Mercer, D. Gile, D. Selescovitch, M. Lederer), взаємозв’язок навчання аудіювання й говоріння в межах професійної перекладацької діяльності й навчання аудіювання як компонента професійної діяльності перекладача (Н.Н. Гавриленко). У межах досліджень педагогічного спрямування розглядались питання формування перекладацької й професійної компетентностей (А.В. Анненкова, Д.І. Бакало, Г. Готов, Я.Б. Смельянова, І.К. Забродіна, О.М. Морозова, С.С. Копилова, Н.М. Соболь, Ю.О. Швецова), перекладу як засобу навчання (Д.Ф. Лок, Х.М. Дадабаєв, І.Ю. Попович, Ю.М. Тельпуховська, А.О. Зайченко), навчання різних видів усного перекладу (В.В. Алєксєєва, Є.В. Белькова, Т.В. Ганічева, Ж.В. Живова, Г.О. Самойленко, Є.О. Червінко), навчання усного перекладу в спеціальних галузях знань (В.В. Бондаренко, Н.М. Гавриленко, Н.В. Кондрашова, О.Б. Павлик, М.Г. Цуциєва), засобів інформаційнокомунікаційних технологій (Н.О. Макоєд, А.В. Янковець). Однак недостатньо уваги приділено теоретичним й емпіричним дослідженням особливостей навчання усного послідовного науково-технічного перекладу (УПНТП) студентів мовних спеціальностей з урахуванням їхньої готовності до навчання УПП.

Мета статті полягає в представленні авторської методики навчання УПНТП з урахуванням рівня готовності студентів до здійснення перекладацької діяльності. Для досягнення зазначеної мети вирішення потребують такі завдання: визначити теоретичні передумови, особливості технології навчання УПНТП й результати експериментального навчання. 
Основні результати дослідження. Розглянувши різні визначення поняття “переклад” i “усний послідовний переклад”, ми сформулювали загальне визначення науковців щодо вказаних термінів й власне визначення, яке деталізувало й доповнило попередні. УПП - усний переклад тексту після слухового та, можливо, паралельного зорового одноразового сприйняття, iз записом чи без запису перекладацьким скорописом, що з огляду на стресовий перебіг перекладацької ситуації й особливості компонентів психологічного змісту УПП супроводжується складними умовами роботи мисленнєвих механізмів (сприйняття, пам'яті, осмислення, переключення з мови оригіналу на мову перекладу тощо). Ми сформулювали визначення поняття “навчання УПП” як процесу взаємодії викладача і студентів з метою мотивації останніх, спрямування їхніх навчальних дій для досягнення максимальних результатів в УПП і контроль ефективності засвоєння вивченого матеріалу та його застосування на практиці.

Для визначення складових перекладацької компетентності (ПК) й підвищення ефективності методики навчання ми проаналізували склад і зміст ПК, пропоновані різними науковцями, 3-поміж яких за спільними ознаками виділено 13, поділені на дві групи: 1) компетентності, сформовані до початку навчання УПП: комунікативні (лінгвістична, прагматична, мовленнєва, лінгвосоціокультурна) й спеціальні (технологічна, дискурсивна, базова, особистісна, соціальна) компетентності; 2) компетентності, які формуються в процесі навчання УПП: предметна, стратегічна, навчально-пізнавальна, психологічна. В межах першої групи визначено компетентності, які не входили до основних цілей методики навчання УПП, але були враховані 3 метою їх удосконалення. До другої групи увійшли компетентності, які формуються лише в процесі навчання УПП та є складовими ПК, характерними для УПП, і були враховані під час визначення цілей навчання.

Професійна мета навчання УПП характеризується демонстрацією студентам реальних перекладацьких ситуацій та ознайомленням зі структурою й жанрами наукового дискурсу 3 подальшим виконанням УПП у галузі відновлювальної енергетики. Практична мета передбачає розвиток й удосконалення складових ПК під час виконання зімітованої перекладацької діяльності. Під виховною метою навчання, що корелює 3 навчально-пізнавальною й психологічною компетентностями, розуміємо вирішення завдань проблемного й проблемно-пошукового характеру й виконання завдань, які імітують реальну професійну перекладацьку ситуацію. Освітня мета реалізується з опертям на навчальні матеріали й передбачає оволодіння предметною й стратегічною компетентностями, зокрема загальнонауковими й спеціальними знаннями понятійної бази в галузі відновлювальної енергетики й факторами впливу на якість перекладу. Розвивальна мета грунтується на розвитку навчально-пізнавальної й психологічної компетентностей шляхом мотивації студентів до самокерованості навчанням, що сприяє саморефлексії, вдосконаленню вміння самостійної роботи, підготовці до УПП шляхом використання інформаційних технологій і визначенню недоліків власних механізмів, які впливають на переклад, для покращення швидкості й якості УПП.

Ефективним методом навчання УПП є комунікативно-ігровий, який реалізується шляхом використання ігрової й інформаційно-комунікаційної технологій навчання: застосування дидактичних і кваліфікаційних ділових ігор, які моделюють реальні перекладацькі ситуації із залученням студентів до само- й взаємооцінювання перекладів, та орієнтація на використання інформаційних технологій навчання.

Унаслідок проведеного комплексного аналізу особливостей психологічного змісту УПП і компонентів готовності студентів до його навчання ми уклали модель УПП, з опертям на яку розробили діагностичну таблицю само- й взаємооцінювання, за якою студенти визначають і деталізують проблеми під час УПП, встановлюють причин їх виникнення й отримують рекомендації щодо їх подальшого уникнення. На відміну від контролю з боку викладача, 
використання діагностичної таблиці само- й взаємооцінювання розвиває у студентів вміння самооцінювання, що підвищує їхню здатність до саморефлексії, сприяє самостійності в навчанні й зміні ступеня керованості ним.

3-поміж основних стратегій німецькомовного наукового дискурсу ми виокремили визначення проблемного питання, аналіз проведених досліджень і проблематики, формулювання мети дослідження й гіпотез, планування вивчення теорії про предмет дослідження, аналіз, оцінювання й демонстрацію результатів експериментів. 3 огляду на варіативність комунікативних завдань виокремлюються три жанри наукового дискурсу: ядерні, периферійні й суміжні. Для методики навчання УПП характерним є суміжний жанр наукового дискурсу, який є граничним між науковим й іншими типами дискурсу, що характеризує використовувані нами навчальні матеріали й комунікативні ситуації: повідомлення, доповіді, інтерв'ю.

Вищеописані результати проведених нами досліджень заклали теоретичне підгрунтя для розроблення методики й створення моделі навчання УПП у галузі відновлювальної енергетики з урахуванням готовності студентів до такого навчання й особливостей ПК.

Дібрані нами засоби навчання студентів з рівнем володіння IM С1 відповідають таким критеріям: автентичність, новизна й актуальність інформації, обсяг залежно від виду перекладу, варіативність типів і жанрів текстів й урахування рівня професійної спрямованості. Оскільки виконання УПП $є$ новим для студентів, для мінімізації їхнього психологічного навантаження на доперекладацькому етапі навчання пропонуємо автентичні публіцистичні статті, які сприяють отриманню предметних знань у галузі відновлювальної енергетики й вправлянню в мікрореферуванні й абзацно-фразовому перекладі, на власне перекладацькому етапі аудіовізуальні матеріали. 3-поміж проаналізованих 243-х текстів й аудіовізуальних матеріалів (загальною тривалістю приблизно 68 год.) ми відібрали 47: науково-популярні фільми, пресконференції, подіумні дискусії, конференції, урядові доповіді, дискусії, інформативні відео й інформаційні програми, які відповідають зазначеним критеріям.

Під час використання основних засобів навчання у запропонованому нами порядку від статей (під час навчання мікрореферування й абзацно-фразового перекладу) до аудіовізуальних матеріалів (під час навчання реферативного перекладу й УПП) - спостерігалась позитивна динаміка навчання УПП. Такий порядок використання навчальних матеріалів є продуктивним: увага студентів сфокусована не на структурі текстів, а на їхньому змісті й лексичному наповненні, а також на розвитку й удосконаленні перекладацьких умінь. У кожній наступній вправі лексика статей ускладнюється, що готує студентів до подальшої роботи з аудіовізуальними матеріалами у послідовності від теленовин й інформативних відео до доповідей і подіумних дискусій. Використання дібраних навчальних матеріалів сприяє зниженню вірогідності виникнення стресу у студентів під час УПП і труднощів, пов'язаних з формою навчальних матеріалів, оскільки поступовий перехід від простих (статей) до складних (аудіовізуальних) матеріалів сприяє комфортній атмосфері як на аудиторних заняттях, так і під час самостійної роботи студентів.

Підсистема вправ для навчання УПНТП, спрямована на формування ПК, уміщує групи й підгрупи вправ, які реалізуються на обох етапах навчання: групи вправ 1-5 на доперекладацькому етапі, група вправ 6 для навчання УПП на рівні тексту - на власне перекладацькому етапі. Метою вправ групи $1 \epsilon$ набуття й перевірка засвоєних декларативних знань про УПП, про його специфіку й визначення факторів впливу на реалізацію перекладу. Цілями вправ груп 2-5 є підготовка студентів до виконання УПП шляхом актуалізації предметних знань у галузі відновлювальної енергетики й послідовного формування навичок і розвиток умінь мікрореферування, абзацно-фразового й реферативного перекладів.

У такий спосіб студенти ще до початку безпосереднього навчання УПП знають, як підготуватися до його виконання, які чинники впливають на успішність перекладацької ситуації та якість тексту перекладу, як залишатись витривалими, уникати стресу й швидкої 
втоми, як правильно реагувати на екстраординарні ситуації й уміти контролювати ситуацію перекладу (на рівні мікрореферування, абзацно-фразового й реферативного перекладу).

Метою вправ групи 6 є формування навичок і розвиток умінь УПП. Студенти удосконалюють предметні знання в спеціальній галузі знань і знання про професійну поведінку перекладача (від отримання замовлення до завершення його виконання). Крім того, студенти розвивають власні стратегії перекладу, вміння аналізу й зіставлення особливостей понять навчального дискурсу двох мов, відбору й обгрунтування обраних перекладацьких стратегій і використання цих умінь на практиці в умовах дефіциту мовних засобів і часу, вміння самостійно тренувати УПП за допомогою інформаційних технологій, визначати й виправляти недоліки перекладу для покращення якості й швидкості перекладацьких дій і тексту перекладу.

Для досягнення максимальних результатів навчання ми використовували ділові ігри 3 елементами перевтілення й ролями, які добирали з урахуванням інтересів і схильностей студентів. Отримавши певну роль, студент підпорядковувався правилам їі поведінки: розвиваючись і виконуючи характерні для реальної перекладацької ситуації завдання. При цьому під час ділової гри студент може виконувати завдання складніші за ті, які на певному життєвому етапі він виконує в повсякденному житті, й ті, які не притаманні його віку. В пропонованій методиці навчання УПП використовуються соціальні, професійні, міжособистісні (клієнт - перекладач, перекладач - колега) й “секретні ролі” (контролююча особа / командний гравець) для підвищення мотивації й ефективності учіння студентів.

Підсистема вправ була реалізована в комплексі вправ за розробленою моделлю організації навчання в межах дисципліни “Усний двосторонній переклад”, що вивчається в I семестрі IV року навчання в Національному технічному університеті України “Київський політехнічний інститут імені Ігоря Сікорського”. Змістовий модуль “УПП у галузі відновлювальної енергетики” складається з шести компонентів: інформативно-мотиваційного вступного заняття-дискусії, вступного заняття з перекладацького скоропису, перекладацької етики й технічної підготовки, трьох навчальних модулів, кожен з яких закінчується навчальною конференцією, і модульної контрольної роботи.

3 метою визначення оптимального режиму роботи в процесі навчання УПП з-поміж індивідуального, парного й у підгрупах, доцільності використання аудіозапису тексту перекладу, визначення мовних особливостей наукового дискурсу в галузі відновлювальної енергетики й труднощів в процесі перекладу ми провели розвідувальний експеримент на IV курсі факультету лінгвістики “Національного технічного університету України “Київський політехнічний інститут імені Ігоря Сікорського”, аналіз результатів якого підтвердив нашу гіпотезу про ефективність навчання у підгрупах і парах, що стимулює взаємодію студентів і сприяє позитивній атмосфері навчання.

Режим виконання вправ - індивідуальний, парний або у підгрупах на власне перекладацькому етапі навчання - був варійованою величиною розвідувального експерименту: в експериментальній групі (ЕГ) 1 студенти виконували вправи індивідуально за допомогою технічних засобів, студенти ЕГ 2 - у парах, студенти ЕГ 3 - у підгрупах. Унаслідок дослідження виявлено, що студенти не готові до самостійного навчання в індивідуальному режимі, оскільки: відчувають дискомфорт під час виконання завдань не з живим слухачем, а записуючи переклад у форматі mp3; немотивовані через постійно відстрочений і вибірковий контроль тексту перекладу з боку інших студентів і викладача; потребують додаткового навчання самостійного вправляння в УПП. У такий спосіб виявлено переваги режимів виконання вправ у парах і підгрупах на власне перекладацькому етапі навчання УПП.

Гіпотеза основного експерименту передбачала досягнення високого рівня сформованості перекладацької компетентності під час виконання УПП у галузі відновлювальної енергетики за таких умов: 1) використання комплексу вправ зі зміною видів перекладу (мікрореферування, 
абзацно-фразовий, реферативний), які логічно передують УПП, у близьких до реальних умовах і з урахуванням готовності студентів до навчання й виконання професійної діяльності; 2) формування й розвитку в них предметної, стратегічної, навчально-пізнавальної й психологічної компетентностей; 3) використання способів контролю, які підвищують здатність студентів до рефлексії (аркуші самооцінювання, діагностична таблиця само- й взаємооцінювання); 4) вибір оптимально ступеня керованості процесом навчання: від жорсткого до гнучкого.

Варійованою умовою експерименту був ступінь керованості процесом навчання: виконання вправ в ЕГ-1 й ЕГ-3 з поступовим переходом від жорсткого до гнучкого ступеня керованості й виконання вправ 3 жорстким ступенем керованості в ЕГ-2 й ЕГ-4. У такий спосіб протиставляється поступовий перехід від керованого викладачем навчання до відносно жорсткого ступеня керованості за участі викладача й студентів до самостійної регуляції студентом власної перекладацької поведінки й визначення власних навчальних і професійних цілей у I варіанті методики і кероване викладачем навчання без послаблення керування діями студентів і постійною участю викладача у II варіанті методики (Задорожна, 2011).

Для ефективного керування процесом навчання й забезпечення зворотного зв'язку між студентами й викладачем нами визначено науково обгрунтовані критерії оцінювання рівня розвитку ПК. Для підвищення ефективності контролю якості УПП вагомим $\epsilon$ контроль з боку викладача (Черноватий, 2013), само- й взаємооцінювання студентів за допомогою таких способів контролю: оцінювання за перспективами (з перспективи викладача, клієнта, слухача, перекладача й колеги-перекладача) за критеріями; діагностична таблиця само- й взаємооцінювання, пропонована після виконання кожного завдання, та контрольний лист самооцінювання студента, який заповнюється після кожного заняття і надає йому відчуття позитивного результату, оскільки наочно демонструє його прогрес у навчанні УПП і формуванні ПК.

Результати експериментального навчання підтвердили ефективність навчання за обома варіантами методики, яка сприяє значному приросту рівня сформованості у студентів ПК. Загалом коефіцієнт навченості студентів усіх ЕГ підвищився в середньому до 0,27. Однак перший варіант методики навчання виявився ефективнішим, оскільки підвищує здатність студентів до саморефлексії й сприяє їх самонавчанню, що дає змогу рекомендувати його до використання в мовних закладах вищої освіти України.

Висновки і перспективи подальших розвідок. Таким чином, представлена в статті методика навчання УПНТП з використанням автентичних навчальних матеріалів, сучасних джерел інформації й інноваційних засобів навчання чинить мотиваційний ефект на студентів. Унаслідок аналізу особливостей психологічного змісту УПП і компонентів готовності студентів до навчання визначено труднощі УПП, виявлено причини їх виникнення й сформульовано рекомендації щодо їх подальшого уникнення. Використання після виконання УПП розробленої діагностичної таблиці само- й взаємооцінювання студентів уможливлює визначення недоліків їхніх мисленнєвих механізмів й отримання рекомендацій для покращення швидкості й якості УПП.

Розроблена підсистема вправ реалізується в їхніх комплексах з урахуванням готовності студентів до навчання в умовах поступового ускладнення вправ (від мікрореферування, абзацнофразового й реферативного перекладу до УПП) і максимально наближеної до реальної перекладацької ситуації з дібраними технічними й нетехнічними навчальними матеріалами, що сприяє поступовому вдосконаленню ПК і зменшенню стресу від навчання й виконанню УПП шляхом орієнтації на зміст, а не на форму навчального матеріалу.

Перспективу подальших досліджень вбачаємо у розробці аналогічних методик навчання УПНТП студентів технічних спеціальностей.

\section{ЛІТЕРАТУРА}

Задорожна, І. П. (2011). Організаиія самостійної роботи майбутніх учителів англійської мови з практичної мовної підготовки [монографія]. Тернопіль : Вид-во ТНПУ. 
Черноватий, Л. М. (2013). Методика викладання перекладу як спеціальності. Вінниця : Нова Книга.

\section{REFERENCES}

Zadorozhna, I. P. (2011). Orhanizatsiia samostiinoi roboty maibutnikh uchyteliv anhliiskoi movy z praktychnoi movnoi pidhotovky [monohrafiia]. Ternopil : Vyd-vo TNPU.

Chernovatyi, L. M. (2013). Metodyka vykladannia perekladu yak spetsialnosti. Vinnytsia : Nova Knyha. 